Abstracta Iranica

Revue bibliographique pour le domaine irano-aryen

Volume 34-35-36 | 2017

Comptes rendus des publications de 2011-2013

\title{
Rika Gyselen. Note de lecture à propos de sceaux administratifs sassanides
}

Julien Cuny

\section{OpenEdition}

1 Journals

Édition électronique

URL : http://journals.openedition.org/abstractairanica/42311

DOI : 10.4000/abstractairanica.42311

ISSN : 1961-960X

\section{Éditeur :}

CNRS (UMR 7528 Mondes iraniens et indiens), Éditions de l'IFRI

\section{Référence électronique}

Julien Cuny, "Rika Gyselen. Note de lecture à propos de sceaux administratifs sassanides », Abstracta Iranica [En ligne], Volume 34-35-36 | 2017, document 36, mis en ligne le 30 juillet 2017, consulté le 04 octobre 2020. URL : http://journals.openedition.org/abstractairanica/42311 ; DOI : https://doi.org/ 10.4000/abstractairanica.42311

Ce document a été généré automatiquement le 4 octobre 2020.

Tous droits réservés 


\title{
Rika Gyselen. Note de lecture à propos de sceaux administratifs sassanides
}

\author{
Julien Cuny
}

\section{RÉFÉRENCE}

Rika Gyselen. « Note de lecture à propos de sceaux administratifs sassanides ». Studia Iranica, 40, 2011, p. 119-135.

1 Commentaires sur les lectures et les interprétations proposées dans la publication de la collection de bulles sassanides conservées au musée de Khoy par D. Akbarzadeh, C.G. Cereti et F. Sinisi (cf. Abs. Ir. 32-33, c.r. n 135). L'A. avance que l'ensemble, en tout ou partie issu de la collection Mochiri constituée au gré d'achats successifs, provient d'archives anciennes différentes et n'est donc pas homogène. L'article est complété par nombre de nouveaux dessins. La numérotation des sceaux administratifs complète la numérotation générale proposée de longue date par l'auteur.

\section{AUTEURS}

\section{JULIEN CUNY}

Musée du Louvre 